\title{
Economic System and Environment: Co-Composting Effect of Prosopis Africana and Cow Dung
}

\author{
Oladipo, Dayo George ${ }^{1} \&$ Emmanuel Okokondem Okon $^{2}$
}

\author{
${ }^{1}$ Department of Chemistry, University of Ilorin, Kwara State, Nigeria \\ ${ }^{2}$ Department of Economics, Kogi State University, Anyigba, Kogi State, Nigeria \\ Correspondence: Oladipo, Dayo George, ${ }^{1}$ Department of Chemistry, University of Ilorin, Kwara State, Nigeria \\ E-mail: oladipodg@yahoo.com.Tel: +2348066146893
}

Received: January 16, 2018

Accepted: January 19, 2018

Online Published: January 28, 2018

\begin{abstract}
An economic system is comprised of the various processes of organizing and motivating labor, producing, distributing, and circulating of the fruits of human labor, including products and services, consumer goods, machines, tools, and other technology used as inputs to future production, and the infrastructure within and through which production, distribution, and circulation occurs. Natural environment refers to climate, weather, and natural resources that affect human survival and economic activity. The natural environment is an important component of the economic system, and without the natural environment the economic system will not be able to function. Hence, in recent years economists have started treating the natural environment in the same way as they treat labor and capital as an asset and a resource. Composting is a biological conversion of heterogeneous organic substrate under controlled conditions, into a hygienic, humus rich and relatively bio-stable product that conditions soil and nourishes plants. The use of compost as a soil conditioner, a fertilizer, or a growth medium has, of course, significant environmental benefits. However, there are also negative impacts on the environment associated with making and using compost. The overall aim of this study is to understand the physicochemical changes such as temperature, conductivity, $\mathrm{pH}$, loss in weight and moisture content that occur during the co-composting of Prosopis Africana shell with cow dung and to assess the way in which these factors influence the quality of the resulting compost and the environment.
\end{abstract}

Keywords: Economic System, Environment, Co-Composting, Prosopis Africana, Cow Dung.

\section{Introduction}

An economic system is comprised of the various processes of organizing and motivating labor, producing, distributing, and circulating of the fruits of human labor, including products and services, consumer goods, machines, tools, and other technology used as inputs to future production, and the infrastructure within and through which production, distribution, and circulation occurs. These processes are overdetermined by the political, cultural, and environmental conditions within which they come to exist (Mtholyoke, n.d.).

The natural environment is a state in which all living and nonliving things occur in a particular region (The DynamicNature, 2014). According to business dictionary (n.d.), natural environment refers to climate, weather, and natural resources that affect human survival and economic activity. The natural environment is an important component of the economic system, and without the natural environment the economic system will not be able to function. Hence, in recent years economists have started treating the natural environment in the same way as they treat labor and capital as an asset and a resource (HigheredMheducation, n.d.).

The maintenance of good soil quality is vital for the environmental and economic sustainability of annual cropping (ARCGIS, n.d.). Composting is a biological conversion of heterogeneous organic substrate under controlled 
conditions, into a hygienic, humus rich and relatively bio-stable product that conditions soil and nourishes plants (Kalaiselvi and Ramasamy, 1996). Co-composting means the composting of two or more raw materials together (SNV, 2016). Co-composting, as ordinary composting is an effective strategy for diverting several types of waste from landfills, while transforming them into valuable resources (Dinis, 2009). According to Manderson (n.d.), compost is the product of the controlled microbial degradation of heterogeneous organic matter into a safe and beneficial humus-like material. The use of compost as a soil conditioner, a fertilizer, or a growth medium has, of course, significant environmental benefits. In addition to returning nutrients to the soil and thus permitting the reduction of artificial fertilizers, compost is waste that does not have to be landfilled. When it is used as daily cover at landfills, it replaces other materials that would otherwise be used for that purpose (UNEP, n.d.).

However, there are also negative impacts on the environment associated with making and using compost. These impacts depend both on the technical approach used and the waste composition of the input streams. Mixed municipal solid waste (MMSW) and sewage sludge composting pose greater risks because these materials typically contain higher levels of heavy metals than do kitchen or yard wastes(UNEP, n.d.).

In this study, co-composting of two feedstock was carried (Prosopis Africana shell and cow dung). Prosopis Africana is a flowering plant species in the genus Prosopis found growing wild in Northern and the Middle-Belt of Nigeria. The proximate composition of the nutritional and functional properties of Prosopis Africana is as follows: moisture, total ash, ether extract, crude protein, crude fibre and carbohydrate, that is, 1.9, 4.4, 12.8, 23.6, 3.3 and 54.0g \% respectively (Aremu et al., 2007). The seeds contained 20.54, 5.67 and $6.51 \mathrm{~g} / 100 \mathrm{~g}$ of protein, ash and fiber, respectively (Barminas, 1998).

The use of cattle manure, or cow dung, in the farms or garden is a popular practice in many rural areas of Nigeria. Cow dung provides high levels of organic materials and rich in nutrients. It contains about 3 percent nitrogen, 2 percent phosphorous, and 1 percent potassium (3-2-1 npk). In addition, one of the other advantages it is very useful for the farmers to use cow dung manure because it contains high levels of ammonia which is potentially dangerous for pathogens (Atulesh, n.d.). By combining the two feedstock/raw materials during composting, the benefits of each can be used to optimize the process and the product (compost).

Generally speaking, this study attempts to determine the physical and chemical transformations that occur during the co-composting of Prosopis Africana shell with cow dung and to assess the way in which these factors influence the quality of the resulting compost and the environment. This investigation is important in enabling us know whether or not compost cannot be considered potentially detrimental or dangerous for the environment or for the human health.

\section{Nigerian Economy and Physical Environment}

\section{Economy}

Nigeria is the most populous country within OPEC. It has around 177 million inhabitants. Located on the Gulf of Guinea on Africa's western coast, Nigeria covers an area of around 924 thousand square kilometers (OPEC, 2018). Nigeria is a middle-income, mixed economy and emerging market, with expanding manufacturing, financial, service, communications, technology and entertainment sectors. It is ranked as the 21 st-largest economy in the world in terms of nominal GDP, and the 20th-largest in terms of purchasing power parity. It is the largest economy in Africa; its re-emergent manufacturing sector became the largest on the continent in 2013, and it produces a large proportion of goods and services for the West African subcontinent (Wikipedia, n.d.a). In addition, the debt-to-GDP ratio is 11 percent, which is 8 percent below the 2012 ratio (Reuters Staff, 2014).

Nigerian GDP at purchasing power parity (PPP) had almost tripled from $\$ 170$ billion in 2000 to $\$ 451$ billion in 2012, although estimates of the size of the informal sector (which is not included in official figures) put the actual numbers closer to $\$ 630$ billion. Correspondingly, the GDP per capita doubled from $\$ 1400$ per person in 2000 to an estimated $\$ 2,800$ per person in 2012 (again, with the inclusion of the informal sector, it is estimated that GDP per capita hovers around $\$ 3,900$ per person). The Table 1 shows a trend of gross domestic product of Nigeria at market prices estimated by the International Monetary Fund with figures in USD billions (IMF, 2006). Figures before 2000 are backwards projections from the 2000-2012 numbers, based on historical growth rates, and should be replaced when data becomes available. The figure for 2014 is derived from a rebasing of economic activities earlier in the year.

Table 1: Economic Indicators of Nigeria

\begin{tabular}{lllll}
\hline Year & $\begin{array}{c}\text { Gross Domestic } \\
\text { Product, } \\
\text { (PPP, In Billions) }\end{array}$ & $\begin{array}{c}\text { US Dollar } \\
\text { Exchange }\end{array}$ & $\begin{array}{c}\text { Inflation } \\
\text { Index } \\
(\mathbf{2 0 0 0 = 1 0 0})\end{array}$ & $\begin{array}{c}\text { Per Capita } \\
\text { Income } \\
\text { (As \% Of USA) }\end{array}$ \\
\hline 1980 & $* 58$ & 1 Naira & 1.30 & $7 \%$ \\
\hline 1985 & $* 82$ & 3 Naira & 3.20 & $5 \%$ \\
\hline
\end{tabular}




\begin{tabular}{lllll}
\hline 1990 & $* 118$ & 9 Naira & 8.10 & $2.5 \%$ \\
\hline 1995 & $* 155$ & 50 Naira & 56 & $3 \%$ \\
\hline 2000 & 170 & 100 Naira & 100 & $3.5 \%$ \\
\hline 2005 & 291 & 130 Naira & 207 & $4 \%$ \\
\hline 2010 & 392 & 150 Naira & 108 & $5 \%$ \\
\hline 2012 & 451 & 158 Naira & 121 & $7 \%$ \\
\hline 2014 & 972 & 180 Naira & (no data) & $11 \%$ \\
\hline
\end{tabular}

Source: Wikipedia (n.d.a).

Although oil revenues contribute $2 / 3$ of oil revenue (Wikipedia, n.d.a), oil only contributes about $9 \%$ to the GDP. Nigeria produces only about $2.7 \%$ of the world's oil supply (in comparison, Saudi Arabia produces $12.9 \%$, Russia produces $12.7 \%$ and the United States produces 8.6\%)(Wikipedia, n.d.b). Although the petroleum sector is important, as government revenues still heavily rely on this sector, it remains a small part of the country's overall economy(see Figure 1 for general economic activities in Nigeria).According to a Citigroup report published in February 2011, Nigeria will get the highest average GDP growth in the world between 2010 and 2050 (Wikipedia, n.d.a). Nigeria is one of two countries from Africa among 11 Global Growth Generators countries.

In spite of the oil, agriculture remains the base of the Nigerian economy, providing the main source of livelihood for most Nigerians. The sector faces many challenges, notably an outdated land tenure system that constrains access to land (1.8 ha/farming household), a very low level of irrigation development (less than 1 percent of cropped land under irrigation), limited adoption of research findings and technologies, high cost of farm inputs, poor access to credit, inefficient fertilizer procurement and distribution, inadequate storage facilities and poor access to markets have all combined to keep agricultural productivity low (average of 1.2 metric tons of cereals/ha) with high postharvest losses and waste (FAO, 2018).

Even though agriculture still remains the largest sector of the Nigerian economy and employs two-thirds of the entire labour force, the production hurdles have significantly stifled the performance of the sector. Over the past 20 years, value-added per capita in agriculture has risen by less than 1 percent annually. It is estimated that Nigeria has lost USD 10 billion in annual export opportunity from groundnut, palm oil, cocoa and cotton alone due to continuous decline in the production of those commodities. Food (crop) production increases have not kept pace with population growth, resulting in rising food imports and declining levels of national food self-sufficiency. The main factors undermining production include reliance on rainfed agriculture, smallholder land holding, and low productivity due to poor planting material, low fertilizer application, and a weak agricultural extension system amongst others (FAO, 2018).

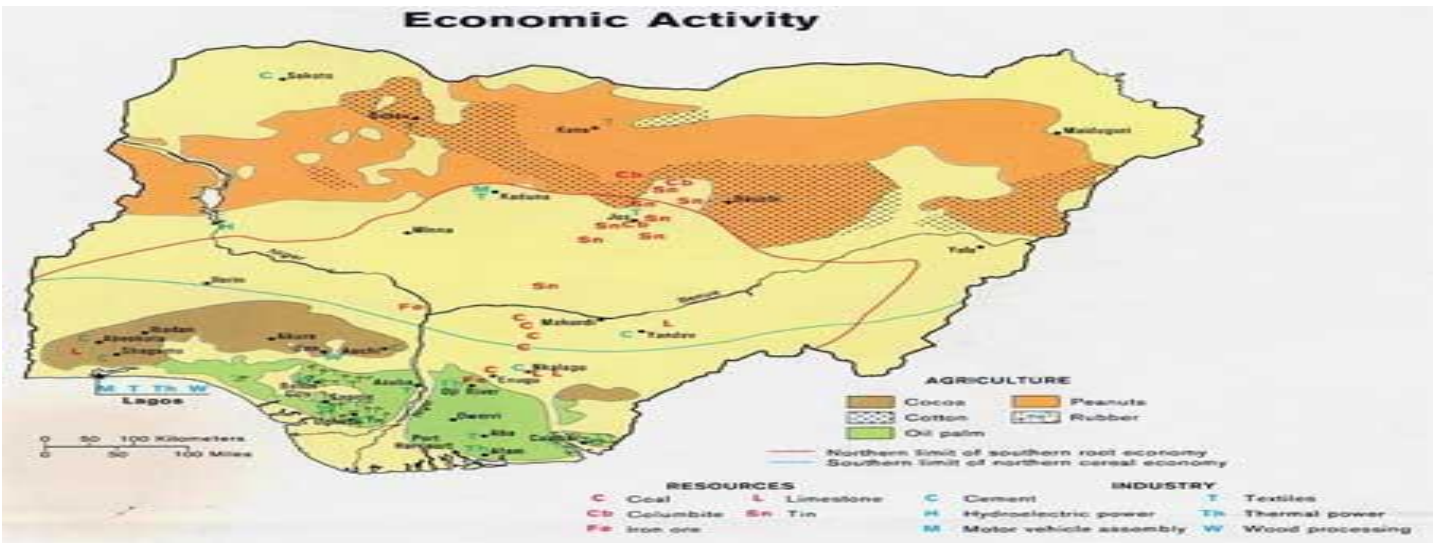

Figure 1: Map of Nigeria showing economic activities

Source:Aregheore (n.d.).

\section{Physical Environment}

Due to its peculiar geographical, geological and geomorphological setting, the Nigerian environmental system is characterized by the combination of natural features that make it uniquely susceptible and highly fragile. In ecological terms, Nigeria is a land of extremes and had remained constantly at risk for ages, with the more recent phenomenon of global warming further accentuating the rate of environmental degradation. Some of these unique features include: 
(a) Nigeria is bounded in the south by over $850 \mathrm{~km}$ long active coastline and in the north by a similar length of the Sahara Desert (see Fig. 2). The country is therefore permanently being ravaged by coastline erosion to the south as well as desertification to the north. Global warming is now acting as a catalyst to these two destructive natural forces. Thus, while coastal inhabitants are under constant threats of sea-level rise, and coastal erosion, Nigerians who dwell along the fringes of the Sahara are under the unabating threats of desertification.

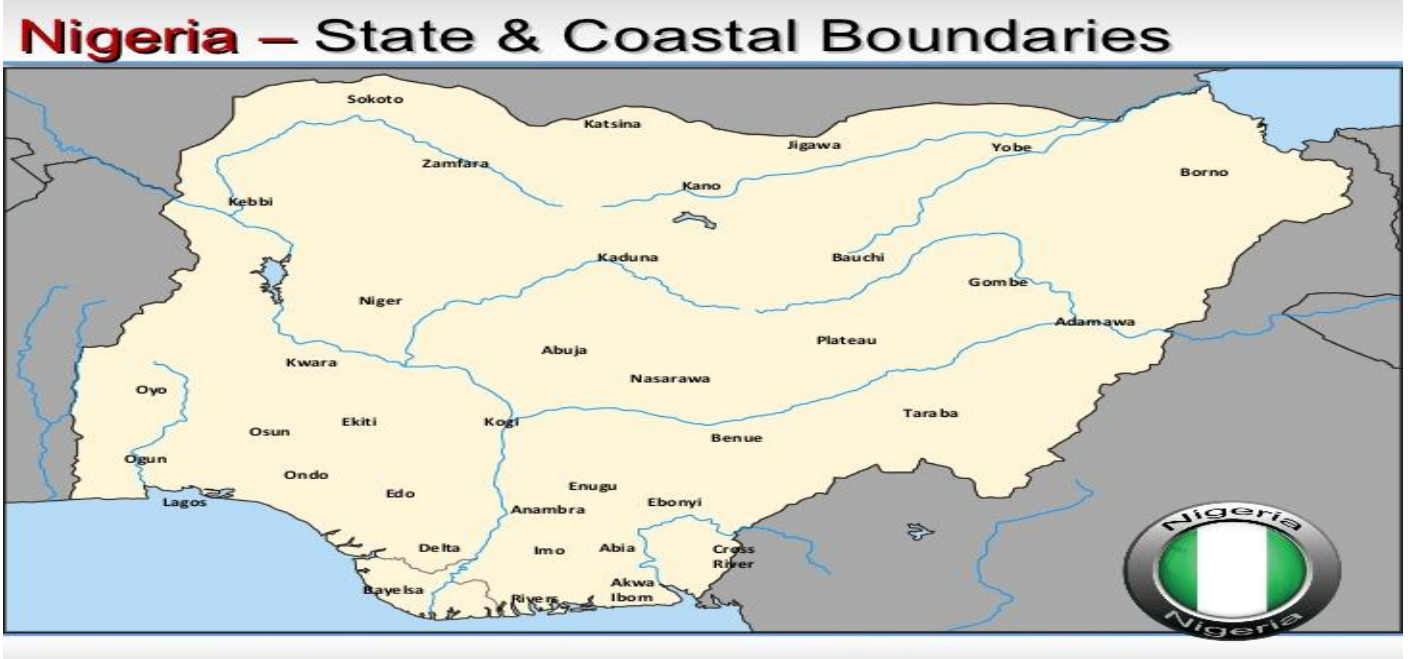

Figure 2: Nigeria: State and Coastal Boundaries

Source: Google(n.d.).

Nigeria map of Köppen climate classification

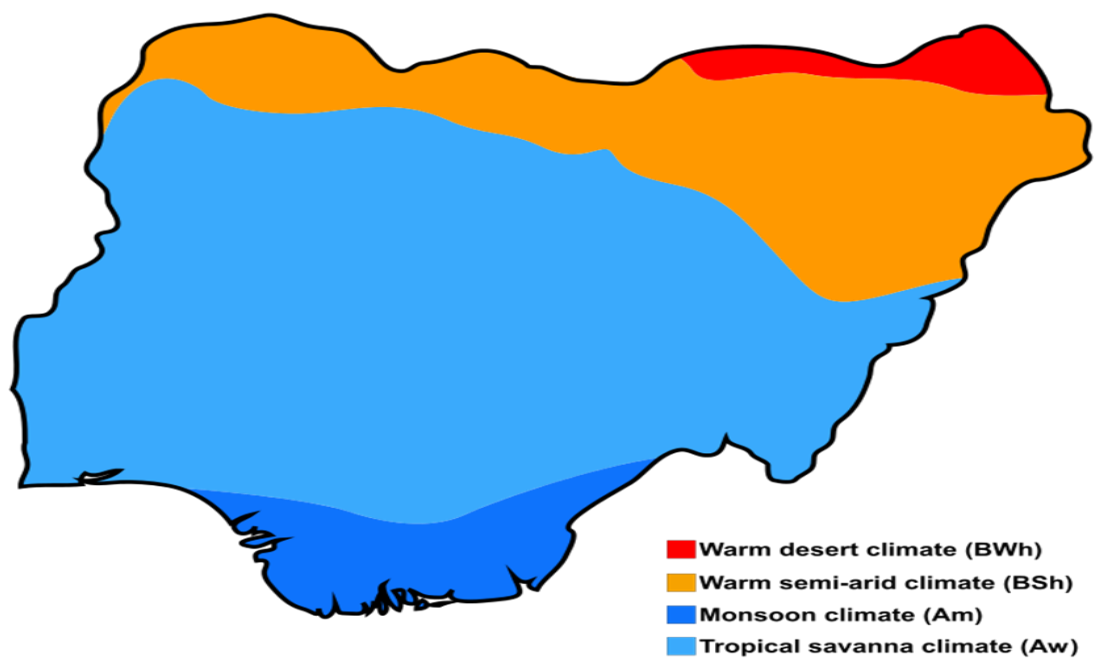

Figure 3: Map of Nigeria showing climate classification

Source: Zifan (n.d.)

(b) The low-lying nature of much of the coastal parts of Nigeria due to its natural geological setting also constitutes a natural threat to the Nigerian environment. Generally, rising to less than 5 metres above sea level, these coastal regions are highly prone to flooding even with small rises in sea level (Ngenvirons, n.d.) (see Figure 3).

(c) Nigeria lies in the middle latitudes in the Gulf of Guinea. It is therefore characterized by generally high and strong wave systems which have more destructive impacts on the shoreline and constantly causing shoreline erosion. (d) Nigeria lies within the equatorial belt characterized by generally high torrential rainfall (Fig. 4). Annual rainfall ranges from over $3000 \mathrm{~mm}$ along the coastline to about $600 \mathrm{~mm}$ in the extreme north(Ngenvirons, n.d.). Even with its short season, rainfall in the north is usually characterized by heavy downpour and high impact torrents, contributing largely to gully erosion. 


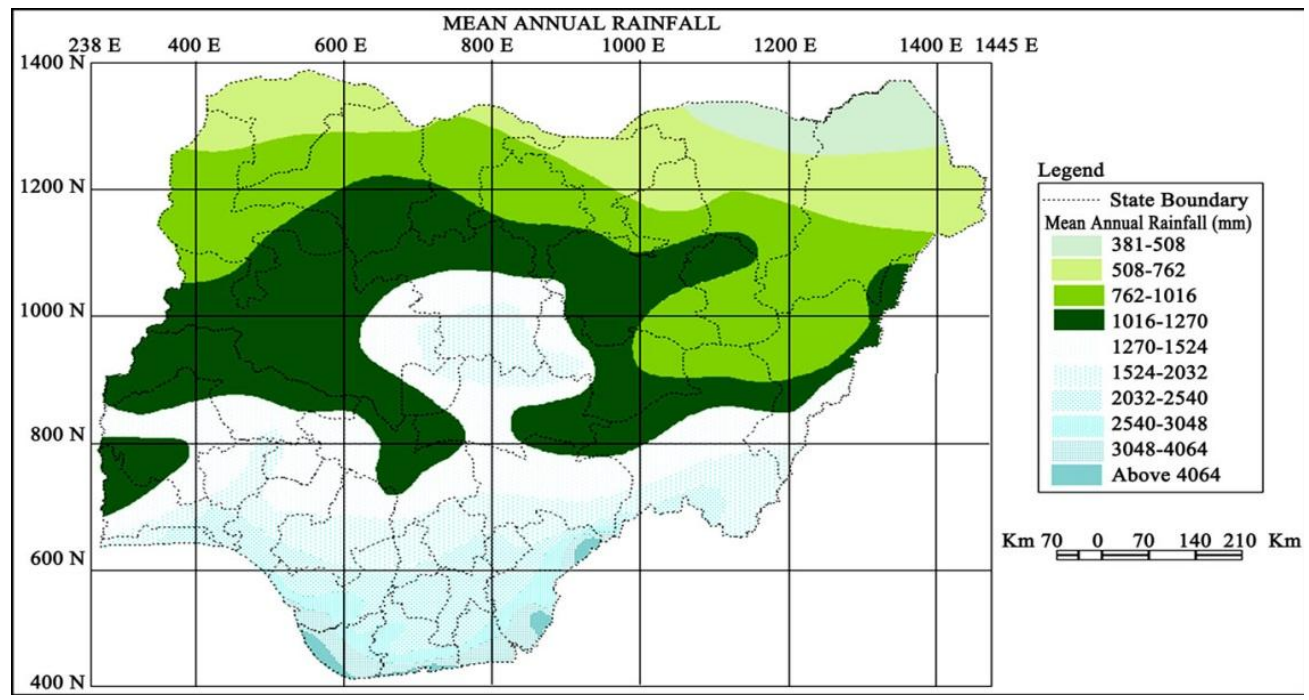

Figure 4: Map of Nigeria showing annual rainfall

Source: Ishaku and RafeeMajid (2010).

(e) Over $40 \%$ of Nigeria's land area is covered by loose Cretaceous Sandstones and deeply weathered Basement Complex rocks giving relatively soft and loose sections near surface (Ngenvirons, n.d.). Such profiles are highly susceptible to gully erosion, especially when combined with torrential rainfall.

\section{Soils}

Soil types in Nigeria are influenced by and follow very broadly, the climatic and vegetational zones of the country. This is expected because the degree of available moisture in the soil is an important factor in soil reactions and fertility and productivity (see Figure 5 for soil fertility of Nigeria: $\mathrm{pH}$ water). The soils of the humid tropical forests are quite different from those of the drier forests and the savanna zone, which in turn are different from the savanna zone (Aregheore, n.d.).

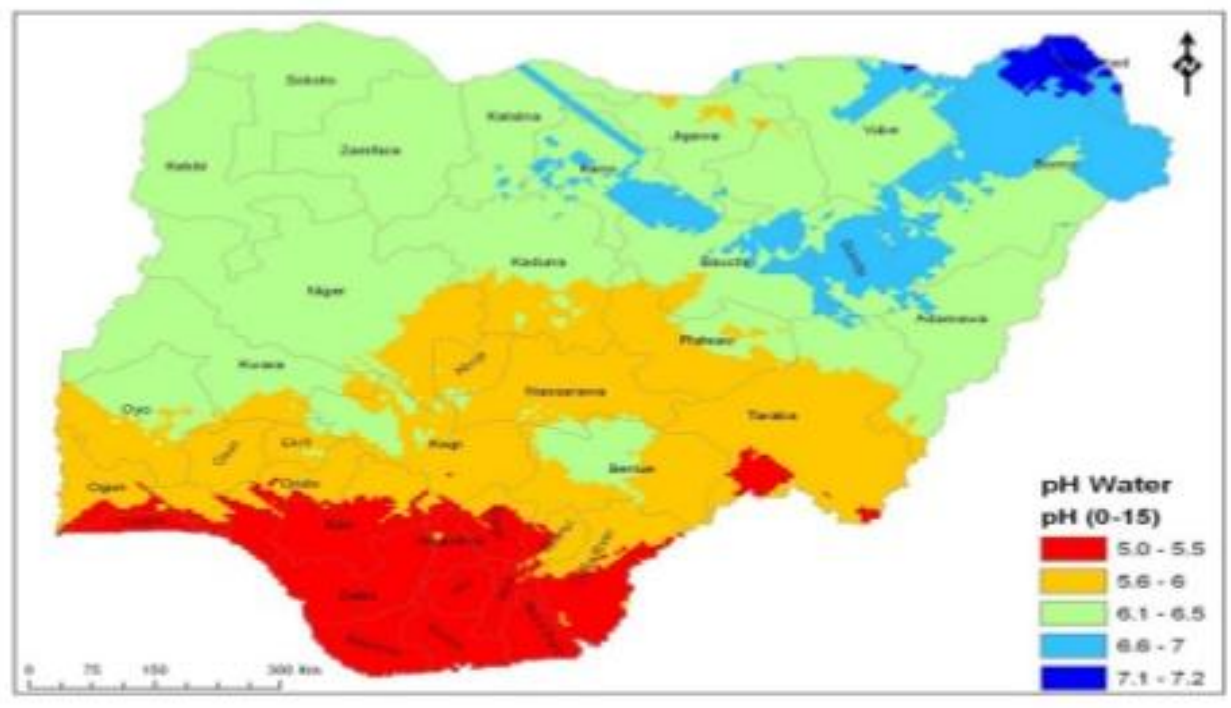

Figure 5: Soil Fertility Map of Nigeria: pH Water

Source: Google (n.d.b).

The major soil types in Nigeria, according to FAO soil taxonomy legends are fluvisols, regosols, gleysols, acrisols, ferrasols, alisols, lixisols, cambisols, luvisols, nitosols, arenosols and vertisols. These soil types vary in their potential for agricultural use (see Table 2).

None of the soils were rated as Class 1 with high productivity by the FAO. In-short over $48 \%$ of the Nigerian soils fall into class 4 and 5, which are mainly vertisols, alisols, acrisols, ferrasols and arensol. These soils usually have low productivity due to inadequate moisture retention capacity and low organic matter. Except for the ferrasols, they are the most dominant types found in the northern dry parts of the country. 
Table 2: Productivity potential of Nigerian soils

\begin{tabular}{llll}
\hline Soil Productivity grade & FAO Productivity Classes & Area & \\
\hline & & $\mathrm{km}^{2}$ & $\%$ of total \\
\hline High (1) & & - & - \\
\hline Good (2) & Fluvisols, Gleysols, Regosols & 50.4 & 5.52 \\
\hline Medium (3) & Lixisols, Cambisols, Luvisols, Nitosols & 423.6 & 46.45 \\
\hline Low (4) & Acrisols, Ferrasols, Alisols, Vertisols & 289.2 & 31.72 \\
\hline Low (5) & Arenosols, Nitosols & 148.8 & 16.32 \\
\hline
\end{tabular}

Source: Adegbola, S.A. (1979).

\subsection{Prosopis Africana in Nigeria}

Prosopis Africana is a multipurpose tree of great economic value among the rural communities in the Guinea savanna of Nigeria (Agboola, 2004). The tree is generally known as Iron wood Tree in Nigeria and itbelongs to the family Minosoceae. It is variously called; Kiriya (Hausa), Ayan (Yoruba), Ubwa (Igbo) and Gbaaye or Kpaaye (Tiv). This list of names is however in-exhaustive, because in North-Central Nigeria the Iron wood tree is widely known and called differently by the many different ethnicities in the region.

The species is widely distributed in the Sahel region of Africa and is native to Africa; occurring from Senegal to Ethiopia throughout the Sudananian and Guinea eco-zones. It is a common deciduous savannah tree throughout West Africa. Like the African Locust bean tree; the Iron wood tree is widely distributed in Nigeria; a common characteristic distribution on farm-lands in North-central states of Nigeria namely Benue, Jos, Kaduna, Kogi, Kwara and Nasarawa States. However, their population in the wild is now threatened because of extended uses and particularly, of its wood for fuelwood and burnt bricks production (Tee et al., 2009).

The fruit of the tree is used as feed for animals, while the seeds are fermented to make ukpehe, a highly proteinaceous condiment. The tree is not cultivated. The products from the hard wood, such as some wooden farm implements, kitchen utensils, and planks for construction, are extensively traded. The tree is a good source of firewood and charcoal. The secondary roots are used as medicine (Agboola, 2004). In summary, Iron wood tree is widely utilized in Nigeria and other African countries for consumption, source of income/employment as well as ecological services.

\subsection{Cow Dung}

Cow dung, also known as cow pats, cow pies or cow manure, is the waste productof bovine animal species. These species include domestic cattle ("cows"), bison("buffalo"), yak, and water buffalo. Cow dung is the undigested residue of plant matter which has passed through the animal's gut. The resultant faecal matter is rich in minerals. Color ranges from greenish to blackish, often darkening soon after exposure to air (Wikipedia, n.d.). Cow dung, which is usually a dark brown color (usually combined with soiled bedding and urine) is often used as manure (agricultural fertilizer). If not recycled into the soil by species such as earthworms and dung beetles, cow dung can dry out and remain on the pasture, creating an area of grazing land which is unpalatable to livestock.

In many parts of the developing world, and in the past in mountain regions of Europe, caked and dried cow dung is used as fuel. Dung may also be collected and used to produce biogas to generate electricity and heat. The gas is rich in methane and is used in rural areas of India and Pakistan and elsewhere to provide a renewable and stable source of electricity (Denmark, n.d.).

In central Africa, Maasai villages have burned cow dung inside to repel mosquitos. In cold places, cow dung is used to line the walls of rustic houses as a cheap thermal insulator. Most of villagers in India spray fresh cow dung mixed with water in front of the houses to repel insects. It is also dried into cake like shapes and used as replacement for firewood (Wikipedia, n.d.). In Nigeria, traditionally, cow dung is used as a fertiliser, though today dung is collected and used to produce biogas (Essiet, 2015).

3. Literature Review: Composting

A review of literature has revealed a wide variation in compost quality and characteristics. Dresbøll and ThorupKristensen (2005) investigated the physical properties of produced compost and the process parameters of composting based on plant residue feedstock from three different species of plants (wheat, hemp, and miscanthus). The authors indicated that different plant feedstocks changed the texture of the compost produced noticeably, affecting parameters like water retention, particle size distribution, $\mathrm{C} / \mathrm{N}$ ratio, and the amount of mineralized nitrogen.

Physical and chemical properties of commercial compost based on their feedstocks and location of origin were investigated by Zmora-Nahum et al. (2007). The authors found that while the compost properties differed widely, there was significant correlation of properties based on the type feedstock. 
Microbes are major drivers of the composting process, and as such, characterization and identification of microorganisms in compost is important to better understand degradation mechanisms. Microbial community structures change during the composting process as temperature and chemical conditions change. Blanc et al. (1999) classified the microbial variety in composts using a combination of population counts and rDNA isolate tests. The authors reported that thermophilic bacteria were being replaced with less thermophilic bacteria as the temperature in the compost pile dropped below optimal ranges for thermophilic bacteria (Blanc et al., 1999).

Fernandez et al.(2008) have evaluated carbon degradation value during co-composting of exhausted grape marc with different biowastes: manure and straw, municipal solid waste and grape straw. They concluded that co-composting of exhausted grape marc not only enhanced the carbon degradation rate, but also reduced the carbon remnant fraction at the end of the composting process (Fernandez et al., 2008).

Tognettiet al., (2005) applied co-composting when mixing municipal organic waste with biosolids and the result showed that this led to improved organic matter concentration therefore enhancing the compost quality and market value while creating products that improve the nutritional capacity of the soil (Tognettiet al., 2005).

The chemical and physical stability of the compost determines the shelf-life and applicability of compost for various uses. A stable compost is one that shows an advanced degree of organic matter decomposition with resistance to further decomposition (Mondiniet al., 2003; Wichuk and McCartney, 2010). A stable compost shows steady values of a number of indices like respiration rates (Wu et al., 2000), microbial count and biomass, organic matter content, $\mathrm{C} / \mathrm{N}$ ratio, and storage temperature (Baffi et al., 2007; Wichuk and McCartney, 2010).

Many phytotoxins, which are compounds detrimental to plant growth, come from agricultural use of pesticides, industrial solvents, propellants, and refrigerants (e.g., halogenated alkanes, alkenes, and aromatic (aryl) hydrocarbons), degradation of waste plastics (polymers, pigments, bulking agents, and filler materials), and storm water runoff. Composting facilitates microbial degradation of organic molecules with phytotoxic properties, and in addition, organic matter generated through composting can bind phytotoxic metals and thereby reduce their bioavailability. Direct germination rates, or a modified germination index (comparison of germination rates of a test vs a control growth media) have been used as indicators of phytotoxicity in composts (Pascualet al., 1997; Tiquia et al., 1997; Tiquia and Tam, 1998; Tiquia and Tam, 2000; Wu et al., 2000; Tang et al., 2006; Himanen and Hänninen, 2011).

4. Materials and Methods

Prosopis Africana fruits were collected from Ilorin, Kwara state in the north central zone of Nigeria. The Prosopis Africana shells were washed, dried, separated from their seeds and pulverized and stored in an airtight container at room temperature.

4.1 Preparation of Compost

Prosopis Africana was washed, dried and crushed. Prosopis Africana shells were pulverized and separated from its seeds, $50 \mathrm{~g}$ was weighed into a conical flask and $10 \mathrm{~g}$ of cow dung and added to it in the flask. $60 \mathrm{ml}$ of distilled water was added and all the components of the flask were thoroughly stirred together. It was covered with foil paper and kept at room temperature for decomposition. Samplings were carried out on a weekly basis for seven weeks (7, 14, 21, 28, 35, 42 and 49 days)to monitor the decomposition in terms of loss in weight, change in moisture content, electrical conductivity, $\mathrm{pH}$ and temperature. The weight was measured using a weighing balance in order to determine the decomposition. The $\mathrm{pH}$, electrical conductivity and temperature were measured by preparing $1 \%$ ${ }^{\mathrm{wt}} /{ }_{\mathrm{wt}}$ of compost in water and then oven dried in the oven after each sampling. After each sampling day, the content of the flask were oven dried at $100^{\circ} \mathrm{C}$ for about 30 minutes and a control sample was prepared without cow dung amendment. $1 \% \mathrm{w} / \mathrm{w}$ of the sample was taken at every 7 days interval. The electrical conductivity was measured using EC214 conductivity meter and $\mathrm{pH}$ was measured using Inolab $7310 \mathrm{pH}$ meter. The temperature, conductivity and weight of the selected sample was recorded before being oven dried. The weight after oven drying was also recorded so that the discrepancy after oven-drying would correspond to the moisture content.

Temperature, one of the key indicators of composting determines the rate of many biological processes as it indicates the end of the transition from the active phase to the curing phase. This plays a selective role on evolution and succession of microbiological communities (Hassen et al., 2001). In the study, the temperature measurements were taken from the compost during the whole period of decompostion. The results from the table gives a graph of the variation of those parameters measured during the period of decompostion.

5. Results and Discussions

5.1 Presentation of Results

The temperature, electrical conductivity, moisture content, loss in weight and $\mathrm{pH}$ for the composting experiment is presented generally in Table 3. However, the breakdown and dicussion of results were done subsequent tables. 
Table 3: Loss in weight, moisture content, $\mathrm{pH}$, electrical conductivity and temperature of composting experiment.

\begin{tabular}{lllllll}
\hline SN & $\begin{array}{l}\text { Composting } \\
\text { Period (Days) }\end{array}$ & $\begin{array}{l}\text { Temperature } \\
(\mathbf{c} \mathbf{c})\end{array}$ & $\begin{array}{l}\text { Moisture } \\
\text { Content }\end{array}$ & $\begin{array}{c}\text { Loss In Weight } \\
(\mathbf{G})\end{array}$ & Ph & $\begin{array}{l}\text { Electrical } \\
\text { Conductivity } \\
(\mathbf{S} / \mathbf{M})\end{array}$ \\
\hline 1 & 7 & 30.50 & 150.78 & 2.47 & 9.67 & 117.23 \\
\hline 2 & 14 & 30.33 & 161.60 & 2.49 & 8.67 & 105.7 \\
\hline 3 & 21 & 30.67 & 148.94 & 2.34 & 7.87 & 93.26 \\
\hline 4 & 28 & 30.67 & 150.49 & 2.40 & 7.70 & 97.43 \\
\hline 5 & 35 & 29.33 & 154.67 & 2.65 & 8.20 & 64.17 \\
\hline 6 & 42 & 29.17 & 144.88 & 2.66 & 9.00 & 46.23 \\
\hline 7 & 49 & 30.00 & 158.46 & 2.84 & 9.20 & 36.30 \\
\hline
\end{tabular}

Source: Field report

5.2.1 Temperature

Table 4: Temperature $\left({ }^{0} \mathrm{C}\right)$ against composting period (days).

\begin{tabular}{lll}
\hline $\mathbf{S} / \mathbf{N}$ & Composting period (days) & Temperature $\left({ }^{\mathbf{0}} \mathbf{C}\right)$ \\
\hline 1. & 7 & 30.50 \\
\hline 2. & 14 & 30.33 \\
\hline 3. & 21 & 30.67 \\
\hline 4. & 28 & 30.67 \\
\hline 5. & 35 & 29.33 \\
\hline 6. & 42 & 29.17 \\
\hline 7. & 49 & 30.00 \\
\hline & & Source: Field report
\end{tabular}

\section{Temperature ${ }^{\circ} \mathrm{C}$ against Composting period (days)}

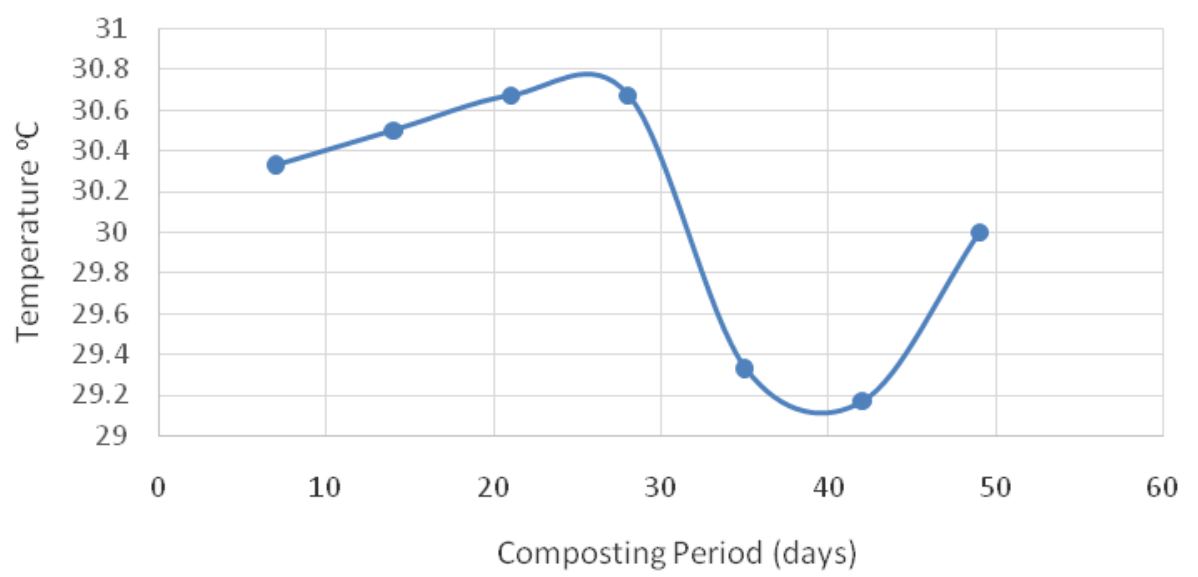

Figure 6: Graph of temperature against the composting period.

Source: Field report

Figure 6 explains the relationship of the temperature with the composting period (days) during composting. Temperature range in this study falls within the acceptable range for composting of organic material. The decomposition of the Prosopis Africana was rapid in the first week of the composting process resulting in increase in temperature of the compost due to the heat liberated by the action of microorganisms that degrade the compost using the surrounding oxygen (Ros et al., 2006). This may be referred to as the active phase of the composting process.

The temperature was maintained at about $30^{\circ} \mathrm{C}$ for a minimum of 14 days to destroy the viability of many pathogens in the mixture. A pathogen is an organism that produces a disease. An example of a very well known pathogenic 
bacteria is Salmonella. There are some 200 immunologically distinguishable types of Salmonella known to be pathogenic to humans. But there are many more that infect animals, including livestock. Cross-infection between people can occur via water pollution. The spreading of untreated or poorly treated compost on land and its use for the irrigation of crops can also be a source of infection (Lenntech, n.d.). However, the temperature of the compost was monitored such that it does not produce so much heat that the compost burst into flame. The second stage; the curing phase, is evident in the graph where the graph steeps down significantly, this occurs during the fourth week. This indicates the lowering of temperature (i.e., dropping to ambient air temperature) when the decomposition is almost over and mesophilic microorganism recolonize the compost. The last phase where the temperature dropped is the maturation phase which is characterized by decrease in temperature (Bernal et al., 2009). Mature compost is a stable material with content called humus that is dark brown or black and has a soil-like, earthy smell (EPA, n.d.). Compost application can improve soil quality and productivity as well as sustainability of agricultural production by replenishing soil organic matter and supplying nutrients (Duong, 2013).

Agriculture is the backbone of the economic system of a given country. In addition to providing food and raw material, agriculture also provides employment opportunities to very large percentage of the population (Agriculture Goods, n.d.). That is why agriculture has been regarded in recent times as the most viable route with which Nigeria can successfully meander from her current economic dilemma (Aikhionbare, 2016).

\subsubsection{Loss in Weight}

Table 7:Loss in weight(g) against composting period(days)

\section{S/N Composting Period (Days)}

\section{Loss In Weight (G)}

\begin{tabular}{lll}
\hline 1. & 7 & 2.47 \\
\hline 2. & 14 & 2.49 \\
\hline 3. & 21 & 2.34 \\
\hline 4. & 28 & 2.40 \\
\hline 5. & 35 & 2.65 \\
\hline 6. & 42 & 2.66 \\
\hline 7. & 49 & 2.84 \\
\hline
\end{tabular}

Source: Field report

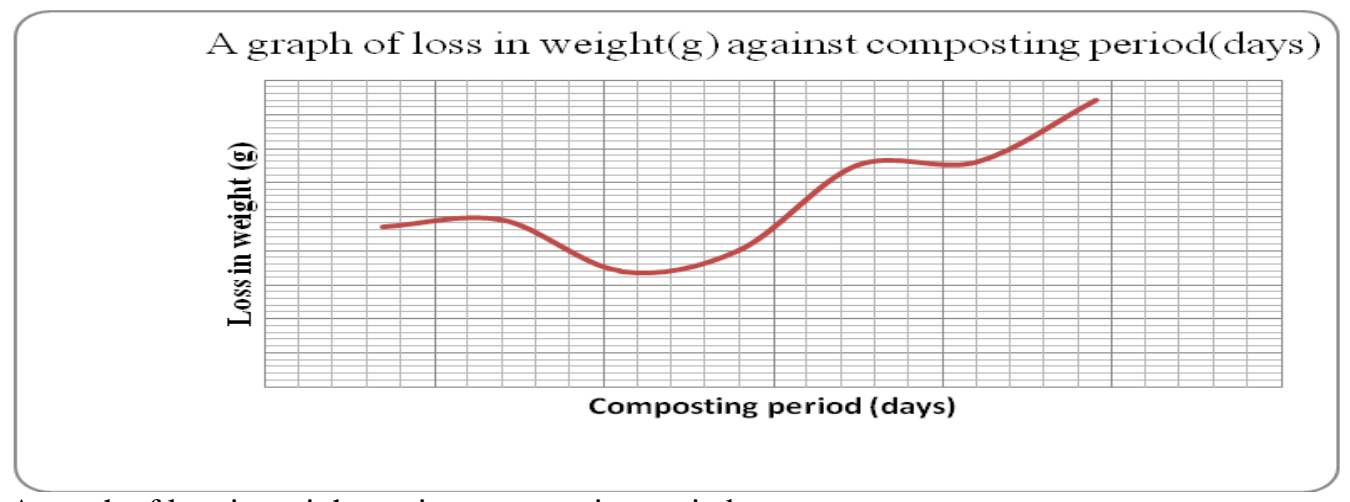

Figure 8: A graph of loss in weight against composting period

Source: Field report

The profile for weight loss was found to drastically increase generally throughout the composting period due to the volatilization losses of nitrogen in the compost (see Figure 8). These gaseous losses can include $\mathrm{NH}_{3}, \mathrm{~N}_{2} \mathrm{O}, \mathrm{N}_{2}$, and possibly other nitrogen oxide compounds (Martins and Dewes, 1992; Körner et al.,1999). Volatilization losses of nitrogen vary depending on the balance with available carbon (Martins and Dewes, 1992; Rynk et al.,1992) and with oxygenation level (Michel and Reddy, 1998). Loss of nitrogen can also result from high ammonium levels at high $\mathrm{pH}$. Concerning the effect of these gaseous losses on the environment, Hao and Benke (2008) observed that the biggest challenge in composting is $\mathrm{N}$ loss, mainly as $\mathrm{NH}_{3}$ and to a lesser extent as $\mathrm{N}_{2} \mathrm{O}$. Ammonia contributes to smog formation and reduces air quality. Near large feedlot operations, high atmospheric NH3 depositions have been linked to plant diversity decline, soil acidification and surface water eutrohication. Emission of $\mathrm{N}_{2} \mathrm{O}$ (greenhouse gas) contributes to global warming and climate change (Hao and Benke, 2008). Scientists and economists are 
beginning to grapple with the serious economic and environmental consequences if greenhouse gases emission is not quickly and deeply reduced (UCS, n.d.). As Forbes (2017) observed, global warming affects the geography within which the global economy operates. It changes growth zones. It changes shorelines. It changes the places where humans will feel comfortable living. In addition, if humans actually decide to do anything about it, it will change the way industry and people use fossil fuels.

\subsubsection{Electrical Conductivity}

Table 9: Values for electrical conductivities (S/m)

\begin{tabular}{lll}
\hline S/N & Composting Period (Days) & Electrical Conductivity (S/M) \\
\hline 1. & 7 & 117.23 \\
\hline 2. & 14 & 105.7 \\
\hline 3. & 21 & 93.26 \\
\hline 4. & 28 & 97.43 \\
\hline 5. & 35 & 64.17 \\
\hline 6. & 42 & 46.23 \\
\hline 7. & 49 & 36.30 \\
\hline
\end{tabular}

Source: Field report

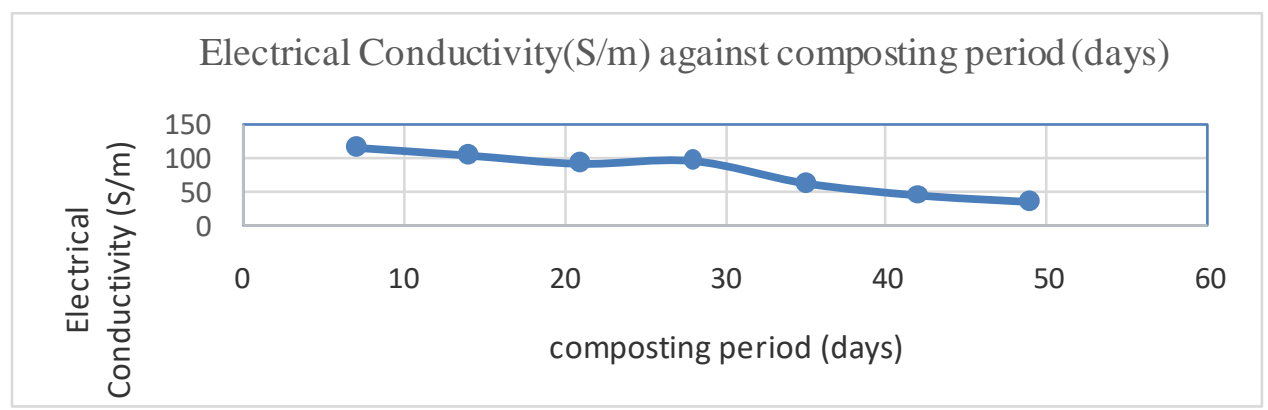

Figure 10: Electrical conductivity (S/m) against composting period (days)

Source: Field report

The highest conductivity was measured at the initial time of decomposition. This graph shows a negative slope which indicates that the amount of free ions in a solution decreases with increasing composting period. The electrical conductivity is actually a measure of salinity. Compost with excessively high salinity can affect plants in the following ways: Specific toxicity of a particular ion (such as Sodium); Higher osmotic pressure around the roots prevents an efficient water absorption by the plant. Some plants are more susceptible to the electrical conductivity than others and each specie has an electrical conductivity threshold, beyond which yield is decreased (Sela, 2017).

\subsubsection{Moisture Content}

Table 10: The values for the moisture content during the composting period

\begin{tabular}{lll}
\hline S/N & Composting Period (Days) & Moisture Content \\
\hline 1. & 7 & 150.78 \\
\hline 2. & 14 & 161.60 \\
\hline 3. & 21 & 148.94 \\
\hline 4. & 28 & 150.49 \\
\hline 5. & 35 & 154.67 \\
\hline 6. & 42 & 144.88 \\
\hline 7. & 49 & 158.46 \\
\hline
\end{tabular}

Source: Field report 


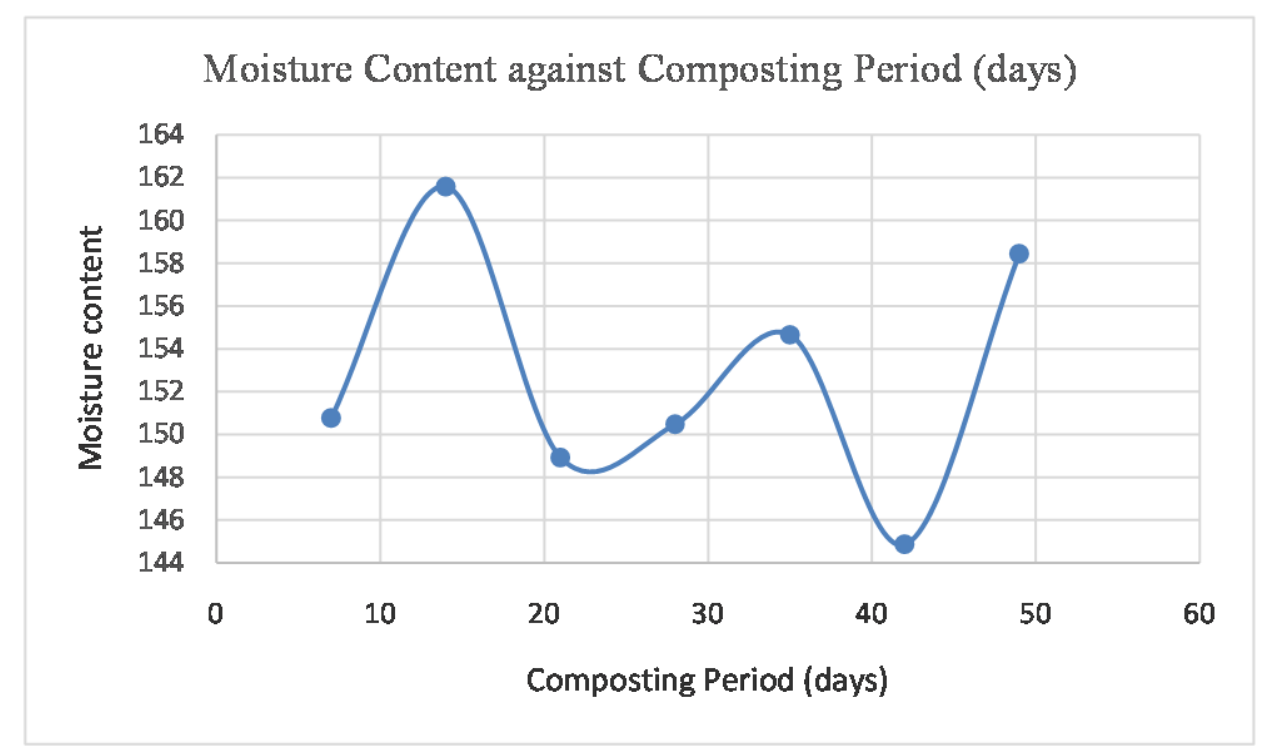

Figure 11: The graph of moisture content against composting period

Source: Field report

The result of this study reveals that the moisture content varies significantly with the temperature profile. Moisture content are important parameters to evaluate maturity of compost (Ameen et al., 2016). Rynk (2000), Haug (1993), Lin et al. (2008), Kuwahara et al (2009) and Nakayama et al (2007) suggested that the optimal moisture content for biological activity is between approximately 40 and 60 percent of the compost's weight. Rynk (2000) also mentioned that the critical moisture content range for supporting spontaneous combustion is around 20 to 45 percent; above this range there is moisture sufficient for the evaporation process to cool the temperature and below it there is insufficient moisture to sustain the biological reaction. Normally, the composting process operates with a moisture content range of between 40 and 70 percent (Haug, 1993). The graph in figure 11 shows that the moisture content increases from the first week as the active phase of the composting process progresses rapidly, the moisture content also decreases during the curing phase according to the graph. The reduction in the value of moisture content at the end of composting is a positive sign of decomposition and it gives mature compost (Epstein et al., 1995).

4.2.4. $\mathrm{PH}$

Table 11: pH versus Composting period (days).

\begin{tabular}{lll}
\hline S/N & Composting period (Days) & PH \\
\hline 1. & 7 & 9.67 \\
\hline 2. & 14 & 8.67 \\
\hline 3. & 21 & 7.87 \\
\hline 4. & 28 & 7.70 \\
\hline 5. & 35 & 8.20 \\
\hline 6. & 42 & 9.00 \\
\hline 7. & 49 & 9.20 \\
\hline
\end{tabular}

Source: Field report 


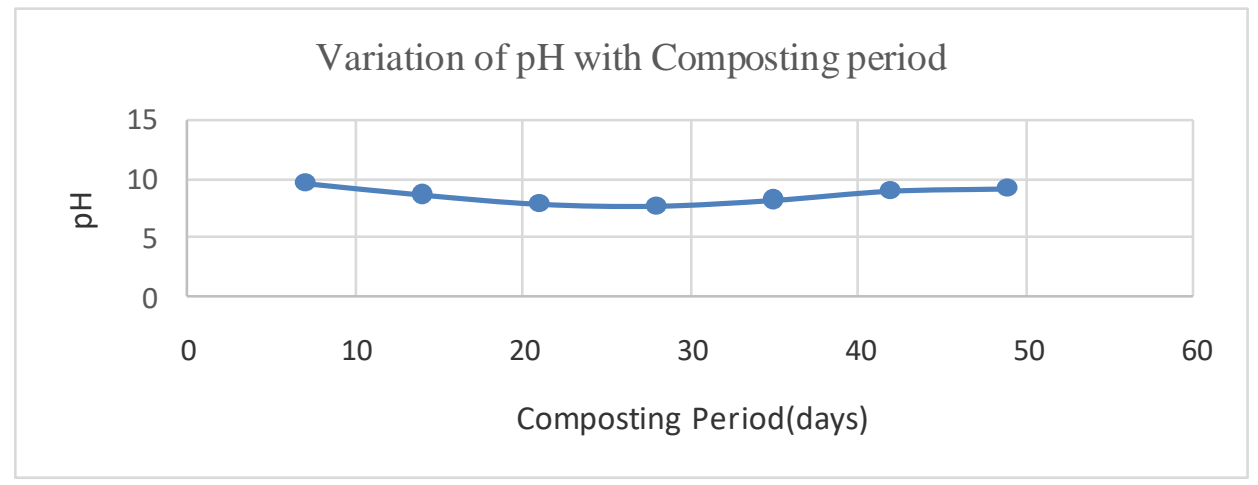

Figure 12: A graph showing the relationship between $\mathrm{pH}$ and the composting period.

Source: Field report

As shown in figure 12, the $\mathrm{pH}$ initially decreases for the first three weeks. During the process of co-composting, the $\mathrm{pH}$ value for the compost tended to stabilize at around 7.79 and 8.10. This slight decrease in $\mathrm{pH}$ was noted in the compost and can be explained by the production of organic acids; dissolved $\mathrm{CO}_{2}$ in the medium and by-products from the degradation of easily degradable compounds such as polysaccharides and fats. Also, a lack of oxygen that can occur between two turnings can result in the production of acids (Kochtitzkyet al., 1969; Mustin ,1987; Peters et al.,2000).

In terms of environment and $\mathrm{pH}$, soil $\mathrm{pH}$ affects the amount of nutrients and chemicals that are soluble in soil water, and therefore the amount of nutrients available to plants. Some nutrients are more available under acid conditions while others are more available under alkaline conditions. However, most mineral nutrients are readily available to plants when soil $\mathrm{pH}$ is near neutral. The development of strongly acidic soils (less than $5.5 \mathrm{pH}$ ) can result in poor plant growth as a result of one or more of the following factors: aluminum toxicity, manganese toxicity, calcium deficiency, magnesium deficiency, low levels of essential plant nutrients such as phosphorus and molybdenum. Alkaline soils may have problems with deficiencies of nutrients such as zinc, copper, boron and manganese. Soils with an extremely alkaline $\mathrm{pH}$ (greater than 9) are likely to have high levels of sodium (Greensland Government, n.d.).

\section{Conclusion and Suggestions During Future Research}

Economic activity is spurred by production which uses natural resources, labor, and capital. It has changed over time due to technology (automation, accelerator of process, reduction of cost functions), innovation (new products, services, processes, new markets, expands markets, diversification of markets, niche markets, increases revenue functions) such as, that which produces intellectual property and changes in industrial relations (Wikipedia, n.d.c). However,wastes are generated by activities in all economic sectors involving loss of materials and energy, and imposes economic and environmental costs on society for its collection, treatment and disposal (Morselli et al., 2008). Composting is a biological conversion of heterogeneous organic substrate under controlled conditions, into a hygienic, humus rich and relatively bio-stable product that conditions soil and nourishes plants (Kalaiselvi and Ramasamy, 1996). Composting has a great importance in economic terms, because it affects a lot and directly into increased productivity culture for which it is used. However, making and using of compost should not be detrimental or dangerous for the environment. The natural environment is an important component of the economic system, and without the natural environment the economic system will not be able to function.

This study has attempted to probe the physical and chemical transformations that occurred during the 49-day composting of Prosopis Africana shell and cow dung and implication on environment. However, for future research, firstly, the variation of the $\mathrm{C} / \mathrm{N}$ nitrogen during the composting period should be monitored and recorded weekly. Secondly, the composting process is an aerobic process and therefore needs adequate supply of oxygen, the use of foil paper to cover the conical flask should be discouraged. Thirdly, graph showing moisture content during the composting period showed that the moisture content did not stabilize at any point, probably implying that the composting of Prosopis Africana shell should take a little longer than 49days before compost maturity is properly reached.

References

Adegbola, S.A. (1979). An Agricultural Atlas of Nigeria, Oxford, University Press, Oxford

Agriculture Goods (n.d.). .The Importance of Agriculture. http://agriculturegoods.com/the-importance-of-agriculture 
Aikhionbare, I. (2016). 5 Roles of Agriculture in Nigeria's Economy. https://infoguidenigeria.com/role-agriculturenigerias-economy/

Ameen , A., Ahmad, J., and Raza, S. (2016). Effect of pH and Moisture Content on Composting of Municipal Solid Waste. International Journal of Scientific and Research Publications, 6(5), 35-37.

Atulesh (n.d.). Cow Dung: A Composted fertilizer. http://www.wealthywaste.com/cow-dung-a-composted-fertilizer ARCGIS (n.d.). Nigeria Soil $\quad$ Types: https://www.arcgis.com/home/item.html?id=40ebf5474ba944caa496ec670cbf3c1b

Aregheore, E. A. (n.d.).Country Pasture/Forage Resource Profiles : Nigeria. http://www.fao.org/ag/agp/agpc/doc/counprof/nigeria/nigeria.htm

Aremu, M.O., Olonisakin, A, Atolaye, B.O., Ogbu, C.F. (2007). Some Nutritional Composition and Functional Properties of Prosopis Africana. Bangladesh Journal of Scientific and Industrial Research, 42(3), 269-280

Baffi, C., Dell', M. T., Abate, A., Nassisi, S. Silva, Benedetti, A., Genevini, P. L. and Adani, F (2007). Determination of Biological Stability in Compost: A Comparison of Methodologies. Org. Waste. Soil. $E G U, 39(1), 1284-1293$.

Barminas, J.T., Maina, H.M., and Ali, J. (1998). Nutrient content of Prosopis africana seeds. Plant Foods for Human Nutrition. 52(4), 325-328.

Bernal, M.P.; Paredes, C.; Sanchez-Monedero, M.A., and Cegarra, J. (1998). Maturity and Stability Parameters of Composts Prepared with a Wide Range of Organic Wastes. Bioresource Technology, 63(1), 91- 99

Blanc, M., Marilley, L., Beffa, T., and Aragno, M. (1999). Thermophilic Bacterial Communities in Hot Composts as Revealed by most Probable Number Counts and Molecular (16S rDNA) methods, FEMS Microbiol. Ecol., 28(1), 141-149.

Businessdictionary (n.d.). Natural Environment. http://www.businessdictionary.com/definition/naturalenvironment.html

Denmark UK (n.d.). Cow Dung - a Source of Green Energy. http://denmark.dk/en/green-living/sustainableprojects/cow-dung-a-source-of-green-energy/.

Dinis, M.A.P. (2009). Co-Composting: A Brief Review. http://bdigital.ufp.pt/bitstream/10284/2333/3/20-30.pdf

Dresbøll, D. B., and Thorup-Kristensen, K. (2005). Structural Differences in Wheat (Triticum aestivum), hemp (Cannabis sativa) and Miscanthus (Miscanthus ogiformis) Affect the Quality and Stability of Plant Based Compost. Sci. Hortic. Amsterdam, 107(1), 81-89.

Ekinci, K.; Keener, H.M., and Elwell, D.L. (2004). Effects of Aeration Strategies on the Composting Process: Part I. Experimental Studies. Trans. ASAE, 47(5), 1697-1708.

Epstein, E. L., Taylor, J. M., and Chancy, R. L. (1976). Effects of Sewage Sludge and Sludge Compost Applied to Soil on some Soil Physical and Chemical Properties. Journal of Environmental Quality, 5(4), 422-426.

EPA (n.d.). Reducing the Impact of Wasted Food by Feeding the Soil and Composting. https://www.epa.gov/sustainable-management-food/reducing-impact-wasted-food-feeding-soil-andcomposting.

Essiet, D. (2015). Biogas: Cow Dung Power for Farmers.http://thenationonlineng.net/biogas-cow-dung-power-forfarmers/ FAO (2018). Nigeria. http://www.fao.org/nigeria/fao-in-nigeria/nigeria-at-a-glance/en/

Forbes (2017). How Does Global Warming Affect The Economy? https://www.forbes.com/sites/quora/2017/07/13/how-does-global-warming-affect-theeconomy/\#41d3725f34a1.

Duong, T.T.T. (2013). Compost effects on Soil Properties and Plant Growth. A Thesis submitted to the University of Adelaide in fulfillment of the requirements for the degree of Doctor of Philosophy. School of Agriculture, Food and Wine, the University of Adelaide.

Greensland Government(n.d.). Soil pH. https://www.qld.gov.au/environment/land/soil/soil-properties/phlevels

Google(n.d.a). Nigeria: State and Coastal Boundaries. https://www.google.com.ng/search?biw=1280\&bih=661\&tbm=isch\&sa=1\&q=map+of+nigeria+showing+c oastal+areas+\&oq=map+of+nigeria+showing+coastal+areas+\&gs_l=psyab.3...997163.999654.0.1004171.11.9.0.0.0.0.810.810.6-1.1.0...0...1.1.64.psyab..10.0.0.4ZhQ5GiO6_w\#imgrc=cbFb5ML_ootLIM:

Google (n.d.b). Soil Fertiliy Map of Nigeria. https://image.slidesharecdn.com/nigeriapriorities-150921132942-lva1app6891/95/nigeria-23-638.jpg?cb=1442842269 
Hassen, A., Belguith, K., Jedidi, N., Cherif, A., Cherif, M., and Boudabous, A. (2001). Microbial Characterization during Composting of Municipal Solid Waste. Bioresource Technology, 80, 217-225.

Hao, X., and Benke, M. B. (2008). Nitrogen Transformation and Losses during Composting and Mitigation Strategies. Global Science Books. http://www.globalsciencebooks.info/Online/GSBOnline/images/0812/DSDP_2(SI1)/DSDP_2(SI1)10180.pdf

Haug, R. T. (1993). The Practical Handbook of Compost Engineering. Lewis Publishers:USA.

Highered.Mheducation(n.d.).Economy and Environment. highered.mheducation.com/sites/dl/free/.../271582/Enviro nment_and_Economy.pdf

Himanen, M., and H"anninen, K. (2011). Composting of Bio-Waste, Aerobic and Anaerobic Sludges - effect of Feedstock on the process and Quality of Compost, Bioresour. Technol., 102, 2842-2852.

IMF (2006).World Economic and Financial Survey.http://www.imf.org/external/pubs/ft/weo/2006/01/data/index.htm

Ishaku, H. T., and RafeeMajid, M. (2010). .X-Raying Rainfall Pattern and Variability in Northeastern Nigeria: Impacts on Access to Water Supply. Journal of Water Resource and Protection, 2(11), 32-40. Article ID: 3187, 8 pages DOI:10.4236/jwarp.2010.211113

Kalaiselvi, T., and Ramasamy, K.. (1996). Compost Maturity: Can it be Evaluated,. Madras Agriculture Journal, 83(10): 609-618.

Körner I, Schlegelmilch, M., and Rainer, S. (1999). Regulation of Nitrogen Contents of Composts during Composting - First Experimental Results. In: Bidlingmaier W, de Bertoldi M, Diaz LF and Papadimitriou EK (eds). Proceedings of the International Conference on Biological Treatment of Waste and the Environment (ORBIT 99), pp 123-129. Berlin. Germany: Rhombos-Verl.

Kochtitzky, O. W., Seaman, W. K.. and Wiley, J. S. (1969). Municipal Composting Research at Johnson City, Tennessee. Compost Sci., 9(4), 5-16.

Kuwahara, F., Sano, Y., Nakayama, A., Nakasaki, K., and Fukazawa, T. (2009). 'Numerical Modeling of a Composting Process with Aeration'. Journal of Porous Media, 12(10), 927-938.

Lenntech (n.d.). Pathogens in Freshwater: Effects of Pathogens in Freshwater Ecosystems. https://www.lenntech.com/aquatic/pathogens.htm.

Lin, Y.P., Huang, G.H., Lu, H.W., and He, L., (2008). 'Modelling of Substrate Degradation and Oxygen Consumption in Waste Composting Processes'. Waste Management, 28(2), 1375-1385.

Manderson, G.J. (n.d.).Composting Agricultural and Industrial Wastes. http://www.eolss.net/samplechapters/c17/e6-58-07-04.pdf

Martins O., and Dewes, T. (1992). Loss of Nitrogenous Compounds during Composting Animal Wastes. Biores Technol 42(1), 103-111.

Michel Jr F.C., and Reddy, C.A. (1998). Effect of Oxygenation Level on Yard Trimmings Composting Rate, Odor Production, and Compost Quality in Bench-Scale Reactors. Compost Sci Util 6(1), 6-14.

Mondini, C., M. T. Dell'Abate, L. Leita, and A. Benedetti (2003). An Integrated Chemical, Thermal, and Microbiological Approach to Compost Stability Evaluation. J. Environ. Qual., 32(1), 2379-2386.

Morselli, L, Vassura, I. , and Passarini, F. (2008). "Integrated Waste Management Technologies and Environmental Control." Sustainable Development and Environmental Management Eds. C. Clini, I. Musu, and M. L. Gullino. Dordrecht: Springer Netherlands, pp.159-170.

Mtholyoke.(n.d.). What is an Economic System?https://www.mtholyoke.edu/courses/sgabriel/econ_system.htm

Mustin, M. (1987). Le Compost : Gestion de la Matière Organique. Editions François DUBUSC 35, rue Mathurin Régnier 75015 paris, 960 pages.

Nakayama, A., Nakasaki, K., Kuwahara, F., and Sano, Y. (2007). 'A Lumped Parameter Heat Transfer Analysis for Composting Processes with Aeration', Transactions of the ASME, 129 (8), 902-906.

Ngenvirons (n.d.).Nigerian Environmental Issues.http://ngenvirons.blogspot.com.ng/ OPEC (2018). Nigeria Facts and Figures. http://www.opec.org/opec_web/en/about_us/167.htm

Paradelo-N'ũnez, R., Rey, R. D., Mendu'inna, A. B. M., and Silva, M. T. B. (2007). Physiologically Based Extraction of Heavy Metals in Compost: Preliminary Results. J. Trace Elem. Med. Biol., 21 (Supplement $1), 83-85$.

Reuters Staff (2014).UPDATE 2-Nigeria Surpasses South Africa as Continent's Biggest Economy.http://www.reuters.com/article/nigeria-gdp-idUSL6NOMY0LT20140406

Ros, M., Garcia, C., Hern andez, T., (2006). A Full-Scale Study of Treatment of Ppig Slurry by Composting: Kinetic Changes in Chemical and Microbial Properties. Waste Manage. 26(10), 1108-1118 
Rynk, R. (2000). 'Fires at Composting Facilities', BioCycle Magazine, vol. 41, pp. 54-58.

Rynk R, van de Kamp, M., Willson, G.B., Singley, M.E., Richard, T.L., Kolega, J.J., Gouin, F.R., Laliberty, Jr L, Day, K., Murphy, D.W., Hoitink, H.A.J., and Brinton, W.F. (1992). On-Farm Composting Handbook. NRAES, Cornell University, Ithaca, New York, USA, 186 pp.

Sela, G. (2017). How Does the Electrical Conductivity Affect Plant Growth? http://www.smartfertilizer.com/articles/ec-1

SNV (2016). Co-composting of Faecal Sludge and Municipal Organic Waste for Sustainable Crop Production in Southern Bangladesh. http://www.snv.org/public/cms/sites/default/files/explore/download/snv_-_cocomposting_of_faecal_sludge.pdf

Tang, J., Maie, N., Tada, Y. , and Katayama, A. (2006). Characterization of the Maturing Process of Cattle Manure Compost. Process Biochem., 41(1), 380-389.

The DynamicNature (2014).What is Natural Environment - Definition of Natural Environment.http://www.thedynamicnature.com/environment/natural-environment-definition.html.

Tiquia, S. M., and Tam, N. F. Y. (2000). Co-Composting of Spent Pig Litter and Sludge with forcedaeration, Bioresour. Technol., 72 (1), 1-7.

Tiquia, S. M., and Tam, N. F. Y. (1998). Elimination of Phytotoxicity during Co-Composting of spent pig-manure sawdust litter and pig sludge, Bioresour. Technol., 65(1), 43-49.

Tiquia, S. M., Tam, N. F. Y., and Hodgkiss, I. J. (1997). Effects of Turning Frequency on Composting of Spent Pig-Manure Sawdust Litter, Bioresour. Technol., 62(1), 37-42.

Tognetti, C., Laos, F., Mazzarino, M.J., and Hernández, M.T. (2005). Composting vs. Vermicomposting: A Comparison of end Product Quality. Compost Sci. Util. 13(1), 6-13.

Tee, T.N., Ogwuche, J.A. and Ikyaagba, E.T. (2009).The Role of Locust Bean and Ironwood Trees in Human Nutrition and Income in Nigeria.Pakistan Journal of Nutrition, 8: 1172-1177.

Wikipedia (n.d.a).Economy of Nigeria.https://en.wikipedia.org/wiki/Economy_of_Nigeria

Wikipedia (n.d.b).Petroleum. https://en.wikipedia.org/wiki/Petroleum\#Production Wikipedia (n.d.c). Economy. https://en.wikipedia.org/wiki/Economy

Wu, L., Ma, L. Q., and Martinez, G. (2000). Comparison of Methods for Evaluating Stability and Maturity of Biosolids Compost. J. Environ. Qual., 29 (1), 424-429.

UCS (n.d.). Climate Hot Map: Global Warming Effects Around the World. http://www.climatehotmap.org/global-warming-effects/economy.html

UNEP(n.d.).1.4.3 Environmental Impacts of Composting IETC.www.unep.or.jp/Ietc/ESTdir/Pub/MSW/SP/SP4/SP4_3.asp.

Wichuk, K. M., and McCartney, D. (2010). Compost Stability and Maturity Evaluation-A Literature Review. Can. J. Civil. Eng., 37(1),1505-1523.

Wikipedia (n.d.). Cow Dung. https://en.wikipedia.org/wiki/Cow_dung

Zifan, A. (n.d.). Nigeria Map of Climate Classification.https://en.wikipedia.org/wiki/Geography_of_Nigeria\#/media/File:Nigeria_map_of_K\%C3\% B6ppen_climate_classification.svg

Zmora-Nahum, S., Hadar, Y., and Chen, Y. (2007). Physico-Chemical Properties of Commercial Composts varying in their Source Materials and Country of Origin. Soil Biol. Biochem., 39 (1), 1263-1276.

\section{Copyrights}

Copyright for this article is retained by the author(s), with first publication rights granted to the journal.

This is an open-access article distributed under the terms and conditions of the Creative Commons Attribution license (http://creativecommons.org/licenses/by/4.0/) 